\title{
Eocene strata from the Sabinas Basin and their bearing in sedimentary basin correlation in NE Mexico
}

\author{
Francisco J. Vega ${ }^{1}$, María del Carmen Perrilliat ${ }^{1}$, Luis Duarte-Torres ${ }^{2}$, \\ Gerardo Durán-Herrera ${ }^{2}$, Roberto Rivas-García ${ }^{2}$, Marcelo Aguilar-Piña ${ }^{3}$, and José F. Ventura ${ }^{4}$ \\ ${ }^{1}$ Instituto de Geología, Universidad Nacional Autónoma de México, Ciudad Universitaria, \\ Coyoacán, México, DF 04510, Mexico. \\ ${ }^{2}$ Minerales Monclova S.A.de C.V., \\ Prolongación Presidente Cárdenas S/N, 26350 Palaú, Coahuila, Mexico. \\ ${ }^{3}$ Instituto Mexicano del Petróleo, Exploración (Geociencias), \\ Eje Central Norte Lázaro Cárdenas 152, Col. San Bartolo Atepehuacan, A. P. 14-805,. México, D.F. 07730, Mexico. \\ ${ }^{4}$ Santa Engracía \#257, Fraccionamiento Santa Elena, Saltillo, Coahuila, Mexico. \\ *vegver@servidor.unam.mx
}

\begin{abstract}
The El Arco section, located on the southeast margin of the Sabinas Basin (Adjuntas Sub-basin), includes a succession consisting of Upper Cretaceous formations typical for this unit, as well as Paleogene strata similar to those previously reported from the La Popa Basin, adjacent to the Sabinas Basin. The El Arco carbonate lentil includes microfossils and nautiloids that indicate a middle Eocene age, which is consistent with previous stratigraphic inferences for the La Popa Basin. The presence of the nautiloid Hercoglossa sp. cf. H. peruviana in the El Arco Lentil and in the upper portion of the Rancho Nuevo Formation of Parras Basin, suggests a new correlation scheme for the Tertiary stratigraphic units of the three basins (Parras, La Popa and Sabinas basins). All three units had sediment input as late as middle Eocene time.
\end{abstract}

Key words: Middle Eocene, Sabinas Basin, basin correlation, Northeastern Mexico.

\section{Resumen}

La sección El Arco, en el margen sureste de la Cuenca de Sabinas (Subcuenca de Adjuntas), incluye una secuencia que abarca formaciones del Cretácico Superior, características de esa unidad, así como estratos del Paleógeno, similares a los previamente reportados para la Cuenca de La Popa, adyacente a la Cuenca de Sabinas. La lente de carbonato El Arco incluye microfósiles y nautiloideos que indican una edad Eoceno medio, lo cual es congruente con inferencias estratigráficas previas para la Cuenca de La Popa. La

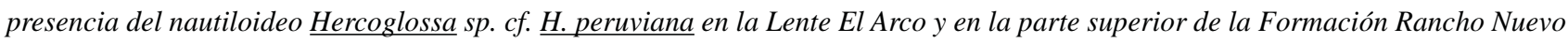
de la Cuenca de Parras, sugiere un nuevo esquema de correlación entre las unidades terciarias de las tres cuencas (Parras, La Popa y Sabinas), las cuales recibieron aporte sedimentario hasta el Eoceno medio.

Palabras clave: Eoceno medio, Cuenca de Sabinas, correlación de cuencas, Noreste de México. 


\section{Introduction}

Data presented here document the presence of Eocene strata in southeast Sabinas Basin (Adjuntas Sub-basin, sensu Flores-Galicia, 1988), and indicate the need for a new correlation scheme between three important Cretaceous - Paleogene depocenters in NE Mexico, known as the Parras, La Popa and Sabinas basins (Figure 1a).

Previously, several authors suggested the presence of Eocene strata in the Sabinas Basin (Chávez-Cabello, 2005; Echánove, 1988; Eguiluz-de Antuñano et al., 2000; Eguiluz-de Antuñano, 2001; 2004; 2007; Eguiluz-de Antuñano and Amezcua, 2003; Gray et al., 2001). Recent field research in the Sierra El Arco on the eastern margin of the Sabinas Basin (Figure 1b) (locality IGM 3599 of the Catálogo de Localidades de la Colección Nacional de Paleontología, UNAM) has revealed the presence of marine Paleogene strata, previously considered as Maastrichtian Hermanas formation by Flores-Espinoza (1989). FloresEspinoza (1989) studied the area recognizing a vertical succession consisting of the Escondido Formation, which includes a red-beds unit, the Múzquiz member, overlain by the Hermanas formation, represented by the El Arco Lentil. The El Arco Lentil was interpreted as a $15 \mathrm{~m}$ thick and 8 $\mathrm{km}$ long carbonate biostrome, deposited during a transgressive phase during low rates of terrigenous sedimentation in Maastrichtian times (Flores-Espinoza, 1989). Based on previous regional reports by Laudon (1975) and McBride et al. (1975), Flores-Espinoza (1989) suggested a relationship between topographic relief associated with diapirism and the deposit on the El Arco Lentil. The elongate shape of the El Arco Lentil suggests its origin adjacent to a former salt wall since evacuated to form a weld, but more fieldwork is necessary to confirm this inference. Recent reports of $\mathrm{La}$ Popa Basin document the relation between carbonate lentils and topographic relief associated with diapirism (Giles and Lawton, 1999; 2002; Lawton et al., 2001).

\section{El Arco Section}

The sequence at El Arco includes outcrops of the San Miguel, Olmos and Escondido formations, all units typical of the Sabinas Basin, as well as outcrops of the upper Potrerillos and Adjuntas formations, typical of the La Popa Basin. The top of the sequence is represented by the El Arco carbonate lentil (Figure 2). A covered interval stratigraphically above the Escondido Formation may correspond to Paleocene deposits, probably equivalent to the Upper Mudstone and Upper Sandstone Members of the Potrerillos Formation. Red beds crop stratigraphically above the covered interval (Figure 3), and are equivalent to the Adjuntas Formation where oyster banks of the species Ostrea (Turkostrea) escondida Perrilliat and Vega, 1993 (Figure $4.1-4.10$ ) crop at the top of the formation. Ostrea (Turkostrea) escondida was also reported from the
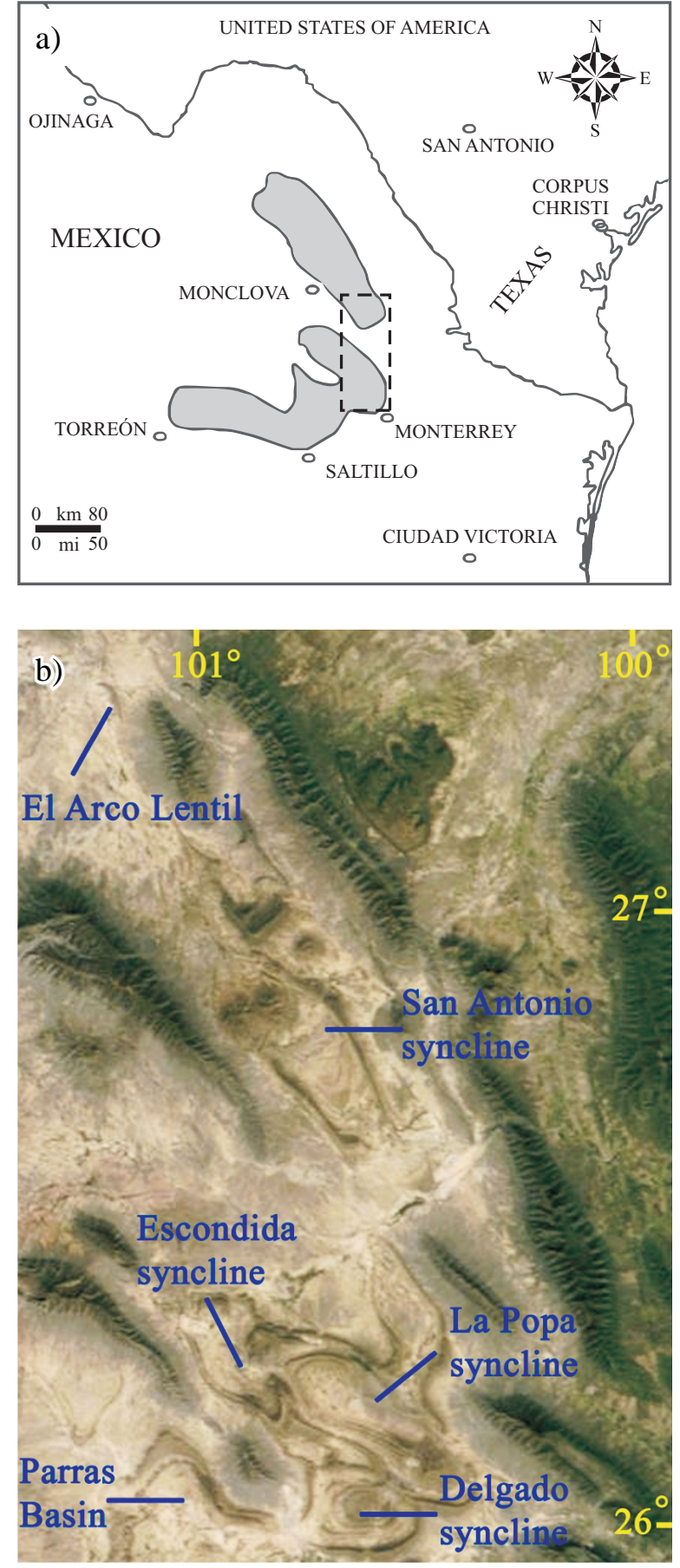

Figure 1. a) Location map of the Parras, La Popa and Sabinas basins. Dashed line rectangle indicates area of figure b) Location map of the El Arco section, southeast margin of the Sabinas Basin and primary synclines of La Popa Basin.

Lower Eocene (Ypresian) of the La Popa Basin (Perrilliat and Vega, 1993) at the La Escondida and San Antonio synclines (Figure 1b). A review of the Múzquiz Member is necessary, as this unit represents, at least in the SE portion of the Sabinas Basin, the Adjuntas Formation, but it is still considered by some, as a Cretaceous unit (Corona-Esquivel 


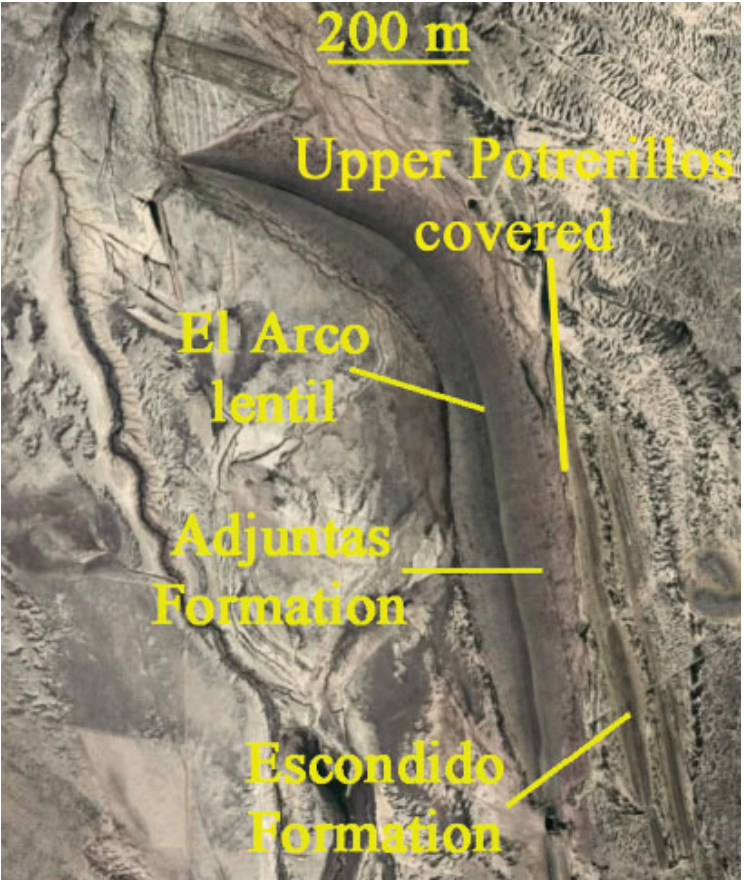

Figure 2. Satellite image of the Sierra El Arco, eastern portion of the Sabinas Basin, with outcrops of the Escondido, upper Potrerillos (covered), Adjuntas and El Arco Lentil.

et al., 2006). Stephenson (1927) reported a new species of Ostrea collected from the Múzquiz formation, mentioning they resemble ostreids of Tertiary forms. However, other authors have reported ammonites from the same unit (Robeck et al., 1956; Flores-Espinoza, 1989). On top of the Adjuntas Formation beds, a $10 \mathrm{~m}$ thick interval of dark-gray limestone, named by Flores-Espinoza (1989) as the El Arco member (Figure 3) of the Hermanas formation, contains numerous fossils that include foraminifera, sponges, solitary corals Flabellum sp. (Figure 5.20-5.22), scarce valves of Venericardia sp., and complete nautiloids identified as Hercoglossa sp. cf. H. peruviana Berry, 1923 (Figure 4.11 - 4.14), a species reported from the Middle Eocene of Perú. Additionally, foraminifera found at the El Arco Lentil (Figure 5.1 - 5.19) suggests a Middle Eocene age, with benthic forms such as Lenticulina jeffersonensis Garrett, 1939 (Figure 5.19), which is used to recognize middle Eocene beds of the Burgos Basin (Aguilar-Piña, pers. comm.). Forms similar to Morozovella aragonensis (Nuttall, 1930) (Figure 5.14, 5.15) also support this interpretation.

\section{Biostratigraphy}

Maastrichtian beds are present in the Parras, La Popa and Sabinas basins. Occurrence of the ammonite Sphenodiscus pleurisepta (Conrad, 1857) indicates an early Maastrichtian age for the Las Imágenes Formation

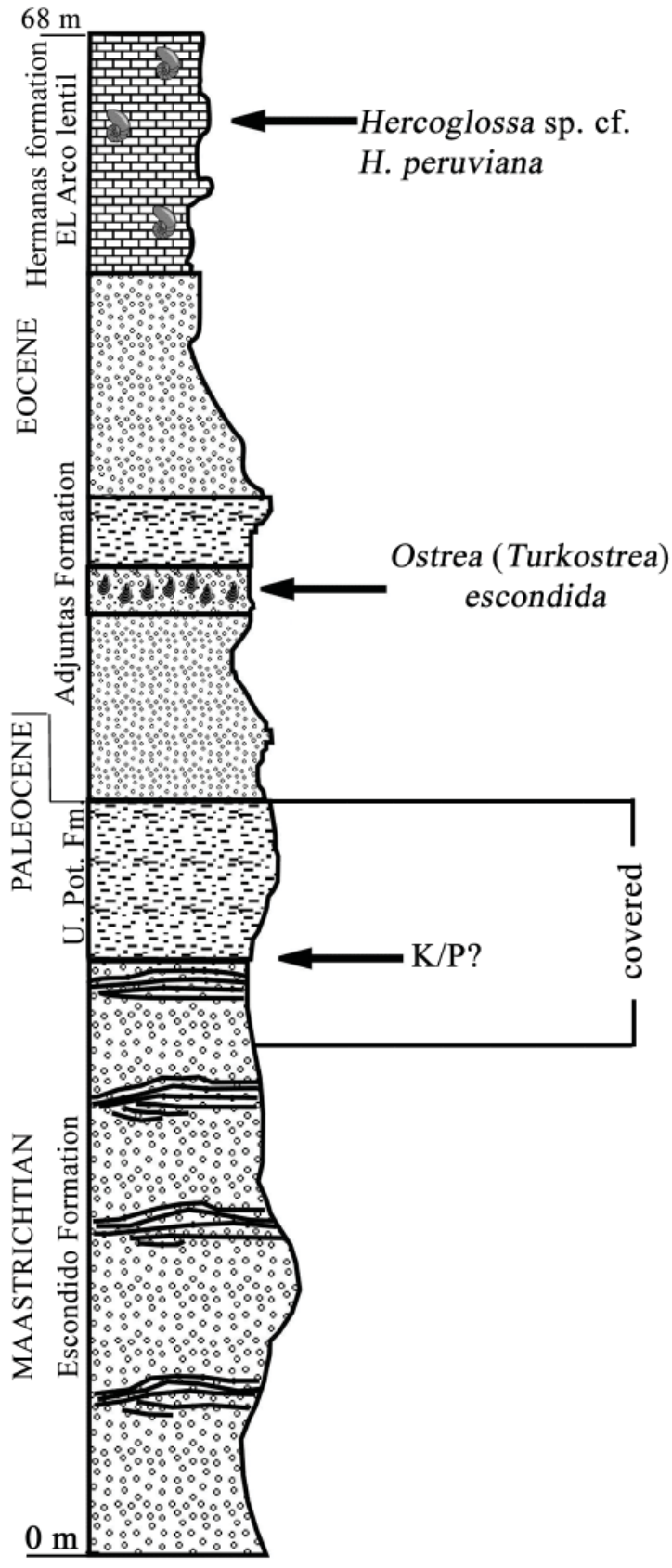

Figure 3. Composite stratigraphic section at El Arco, southeast Sabinas Basin, with Escondido, upper Potrerillos Formation (U. Pot. Fm.), Adjuntas Formation and Hermanas formation, which consists entirely of the El Arco Lentil. Top of section is eroded.

of the Parras Basin (Bermúdez-Santana, 2003; Wolleben, 1977), the Lower Mudstone Member of the Potrerillos Formation of the La Popa Basin (Ifrim, 2005; Vega and Perrilliat, 1989c; Wolleben, 1977), and the Escondido Formation of the Sabinas Basin (Flores-Espinosa, 1989). Cimomia haltomi (Aldrich, 1931) is present in the lower Rancho Nuevo Formation of the Parras Basin (Vega and Perrilliat, 1995; Wolleben, 1977), and the Upper Mudstone Member of the Potrerillos Formation, La Popa Basin (Vega 

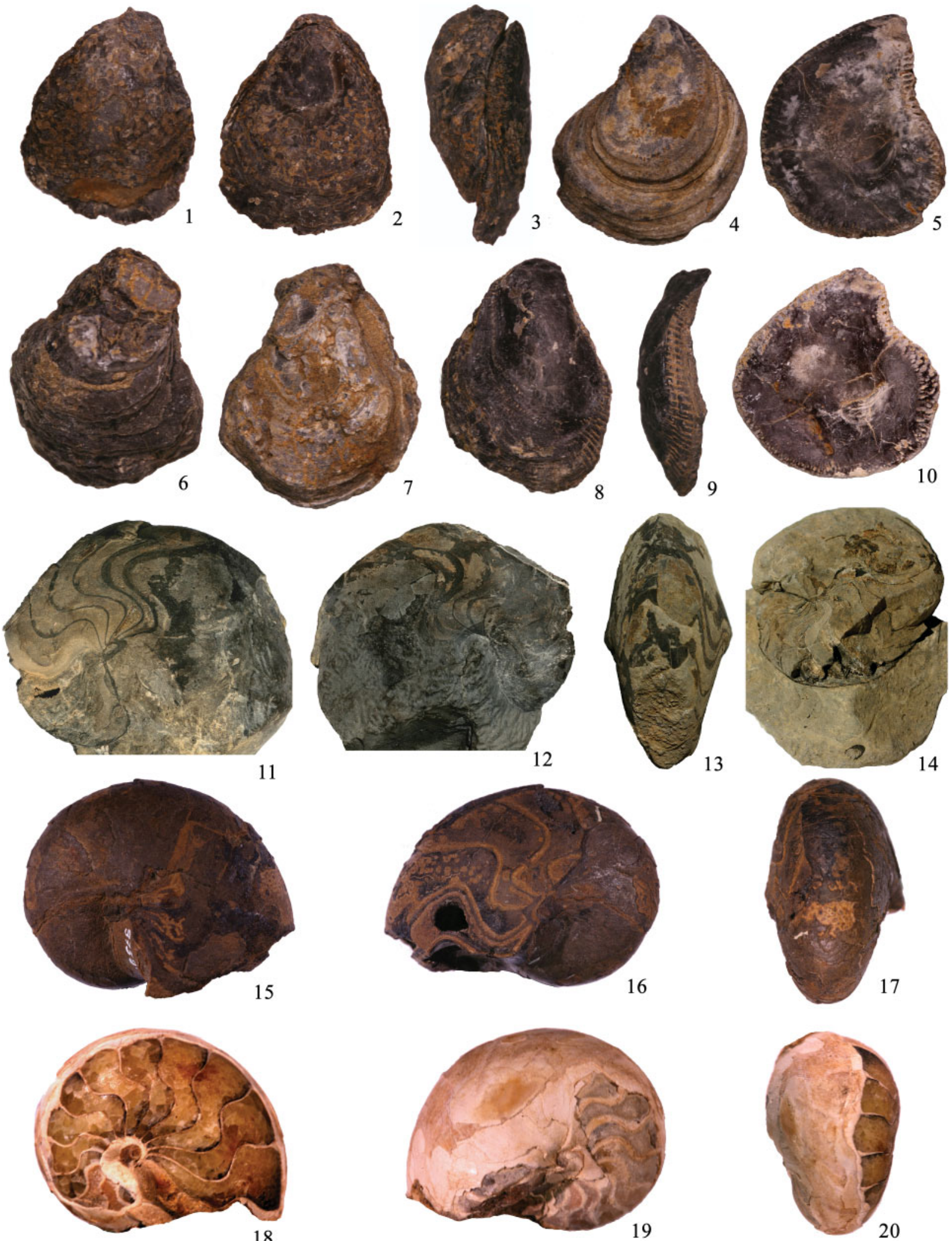

Figure 4. 1 - 10: Ostrea (Turkostrea) escondida Perrilliat and Vega, 1993, El Arco section, Adjuntas Formation, Sabinas Basin, Coahuila, Lower Eocene (Ypresian). 1 - 3: Hypotype IGM-7840, articulated specimen, left valve, right valve and left lateral views, X1.2; 4, 5: Hypotype IGM-7841, right valve, outer and inner views, X1.0; 6, 7: Hypotype IGM-7842, articulated specimen, left and right valves, X1.2; 8, 9: Hypotype IGM-7875, outer and left views of left valve, X1.2; 10: Hypotype IGM-7876, inner view of left valve, X0.8. 11 - 16: Hercoglossa sp. cf. H. peruviana Berry, 1923. 11 - 13: Hypotype IGM7878, right, left and ventral views, El Arco Lentil (Hermanas formation), Sabinas Basin, Coahuila, Middle Eocene (Lutetian), X0. (Continue on next page). 
and Perrilliat, 1995), indicating a Paleocene age for those units. As previously mentioned, no Paleocene strata were recognized at the El Arco section, due to lack of exposure in the upper portion of the Escondido Formation. However, based on a similar stratigraphic sequence observed by Vega et al. (1989) at the San Antonio Syncline, we infer that Paleocene strata equivalent to the Upper Mudstone and Upper Sandstone Members of the Potrerillos Formation are present above the Escondido Formation. The Adjuntas Formation in the La Popa Basin, has been considered to be of early Eocene age on the basis of index fossils such as Venericardia planicosta (Lamarck, 1801), Kapalmerella mortoni postmortoni (Harris, 1894) and turkostreid species, which are closely related to species from other Eocene units in the Tethys Province (Vega and Perrilliat, 1989a; 1989b; 1992; 1995; Vega et al., 1989; Perrilliat and Vega, 1993; 2003; Lawton et al., 2001; Klosterman et al., 2007). Kapalmerella mortoni postmortoni (Figure 5.23 - 5.25) is also abundant in the Viento Formation of the La Popa Basin, and although it was formerly considered as an index fossil for the early Eocene, Allmon (1996; 2005) placed this species in the upper Paleocene. However, an important index fossil found in the Adjuntas Formation is Venericardia planicosta (Figure 5.26), an early Eocene (Ypresian) bivalve. The presence of the Eocene nautiloid Hercoglossa sp. cf. H. peruviana above Adjuntas strata at El Arco section seems to confirm that the succession overlying the Adjuntas (Viento and Carroza formations) is of Eocene age. An interesting addition to the data presented here is the occurrence of Hercoglossa sp. cf. H. peruviana (Figs. 4.15 - 4.17) in the upper part of the Rancho Nuevo Formation (contribution of J. Ventura, locality IGM 3598 of the Catálogo de Localidades de la Colección Nacional de Paleontología, UNAM). Thus a new scheme of correlation is needed for the three main Upper Cretaceous - Paleogene sedimentary basins in Northeastern Mexico. Hercoglossa is also present in the lower Eocene of Chiapas (Figure 4.18 -4.20), shells of which were used to obtain an isotopic age equivalent to $52 \mathrm{Ma}$ (Perrilliat et al., 2006), which corresponds with the Ypresian stage (Steurbaut, 2006). A nautiloid specimen reported by Squires and Demetrion (1992) from the Eocene of Baja California Sur, was reported as being similar to $H$. peruviana.

\section{Correlation}

Flores-Espinoza (1989) proposed a correlation between the Upper Sandstone Member of the Potrerillos Formation
(La Popa Basin) and the El Arco Lentil of the Hermanas formation. However, the Upper Sandstone Member underlies the Adjuntas Formation at the Delgado, La Popa, La Escondida and San Antonio synclines (Figure 1b). In the hinge of the San Antonio Syncline on the southernmost edge of the Sabinas Basin, Vega et al. (1989) recognized Paleocene strata (upper Potrerillos Formation) that overlie Maastrichtian deposits of the Escondido Formation containing Sphenodiscus pleurisepta. Although oyster beds of Ostrea (Turkostrea) escondida were recognized from the top of the Adjuntas Formation in this section, the calcareous equivalent found at the top of El Arco section is not present. Soegaard et al. (2003) also suggested a correlation of the section in the southern part of the Sabinas Basin at the San Antonio Syncline, with the upper portion (Paleocene) of the Parras and La Popa basins. They considered the Rancho Nuevo Formation (Parras Basin) to be correlated with the Paleocene Upper Mudstone Member of the Potrerillos Formation (La Popa Basin), and that the Adjuntas, Viento and Carroza Formations (La Popa Basin) of Eocene age, were deposited during the last stratigraphic cycle in the Difunta Group.

On the basis of previous stratigraphic interpretations and recent findings at El Arco, we suggest a new scheme of correlation between the Paleogene sections of three important sedimentary basins in northeastern Mexico (Figure 6). The Paleogene units at the Sabinas Basin are represented by the upper Potrerillos Formation, the Adjuntas Formation and the El Arco Lentil of the Hermanas formation. These units are equivalent to the Paleocene Upper Mudstone and Upper Sandstone Members of the Potrerillos Formation, and to the Lower Eocene Adjuntas Formation, and the basal middle Eocene Viento and Carroza formations of the La Popa Basin, respectively (Figure 6). Occurrence of the nautiloid Hercoglossa sp. cf. H. peruviana on the upper part of the Rancho Nuevo Formation in the Parras Basin suggests a direct correlation with strata of the Sabinas Basin, and indirectly with the upper part of the section in La Popa Basin. Sediment was being supplied to the three basins during middle Eocene time, possibly the beginning of the Lutetian, while seas were retreating from W-SW to E-NE in Northeastern Mexico (Figure 7).

\section{Conclusions}

Presence of marine Eocene strata in the eastern part of the Sabinas Basin, suggests a correlation with the La Popa and the eastern Parras basins. The stratigraphic range of the

Figure 4. (Continued). 3. 14: Hypotype IGM-7879, left side of specimen in a concretion, with a specimen of Flabellum sp. included, El Arco Lentil (Hermanas formation), Sabinas Basin, Coahuila, Middle Eocene (Lutetian), X0.3. 15 - 17: Hypotype IGM-7877, right, left and ventral views, locality IGM 3598, Noria Las Ánimas, upper Rancho Nuevo Formation, Parras Basin, Coahuila, Middle Eocene (Lutetian), X0.8. 18 - 20: Hercoglossa sp., hypotype IGM-8622, right, left and ventral views, Veinte de Noviembre, El Bosque Formation, Chiapas, Lower Eocene (Ypresian), X1.0. 


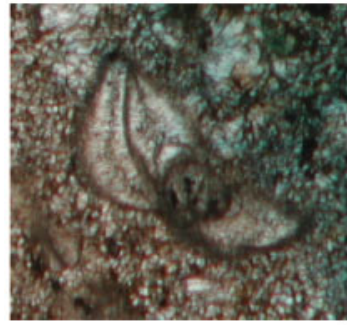

1

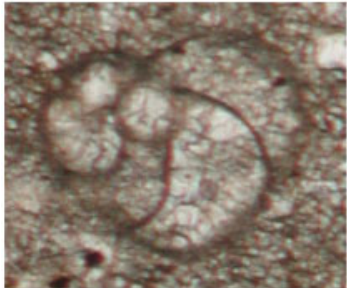

6

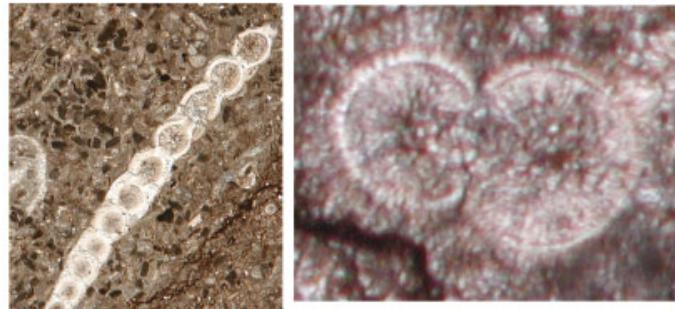

16

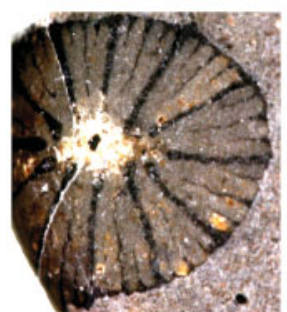

21

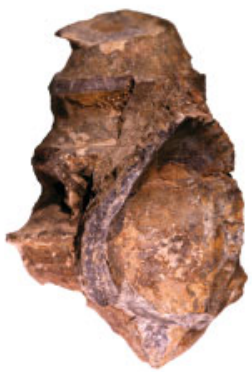

23
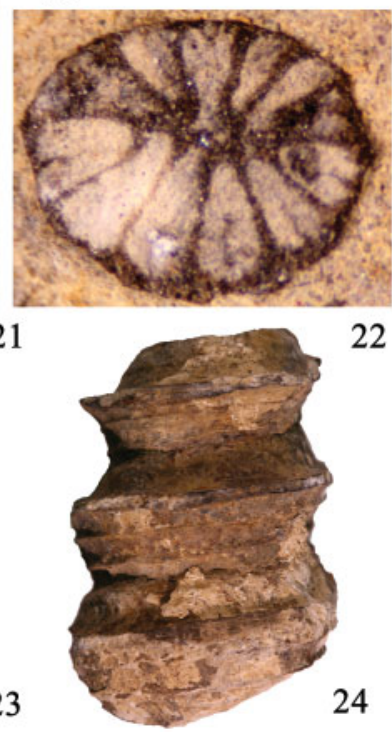

12

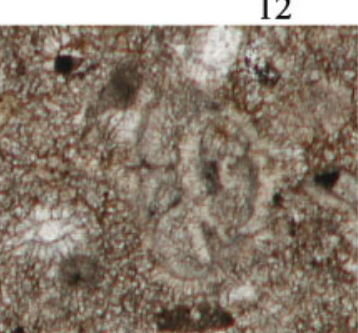

2

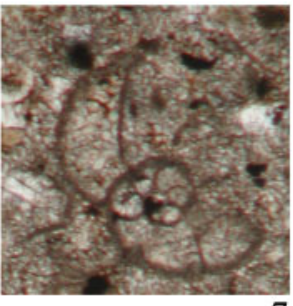

7

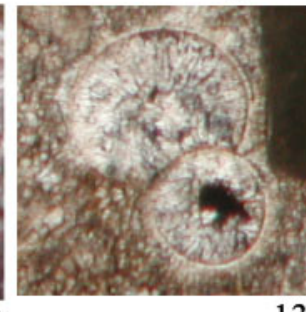

13

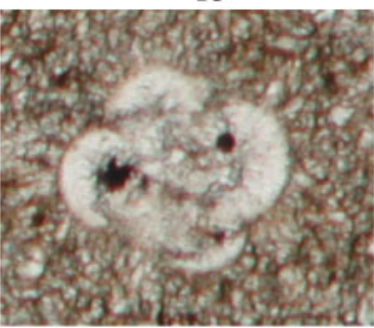

17
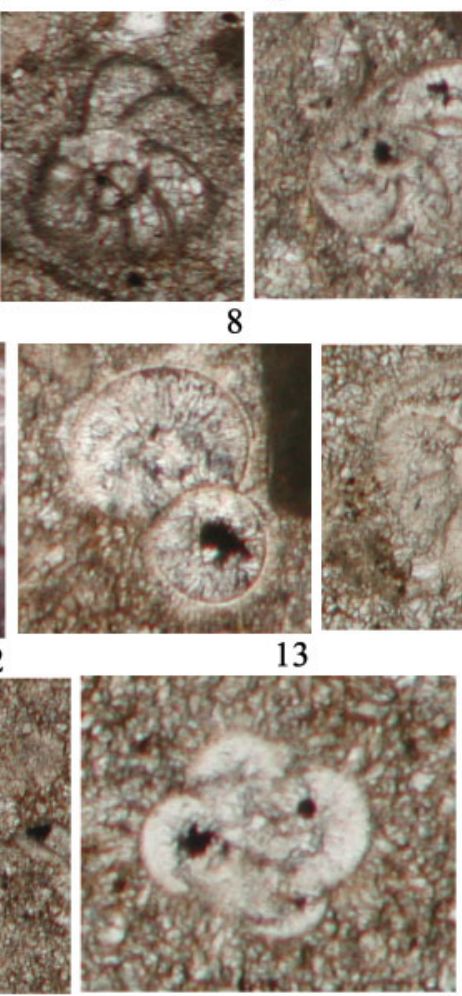

18

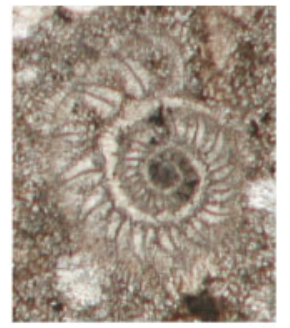

3

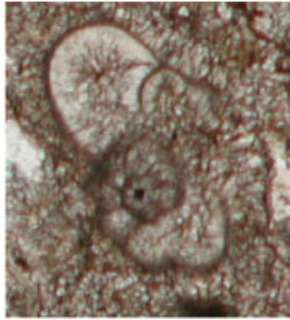

4

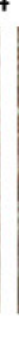

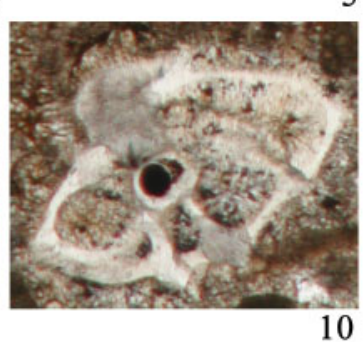

10

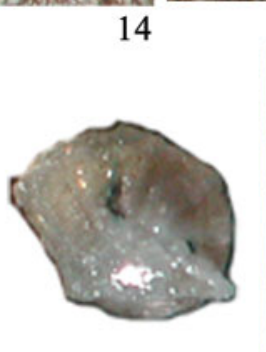

19

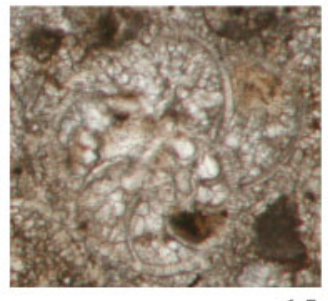

15

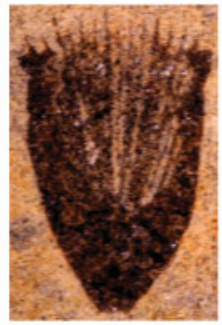

20
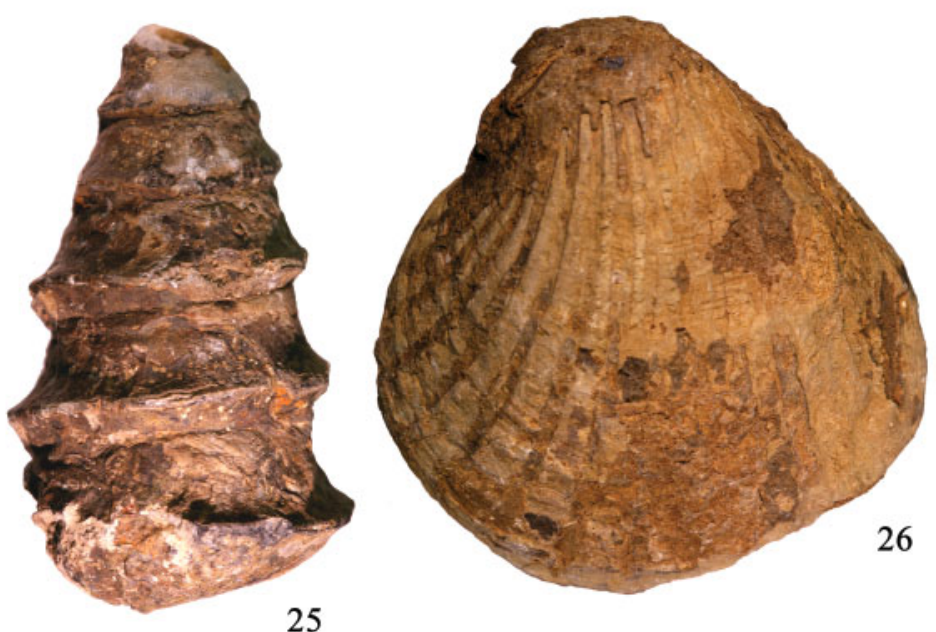

25

Figure 5.1 - 19: Foraminifera, locality IGM 3599, El Arco Lentil, Hermanas formation, Sabinas Basin, Coahuila, Middle Eocene (Lutetian). 1, 2: Gyroidinoides sp. 1: Axial section, 36X. 2: Equatorial section, 36X. 3: Cibicidoides sp., surficial equatorial section, 36X. 4 - 8: Valvulamminidae Loeblich and Tappan, 1986, equatorial section, 48X. 9: Hanzawaia sp., equatorial section, 90X. 10: Rotaliid, axial section, 48X. 11: Siphonodosaria sp., axial section, 10X. 12, 13: Pseudoglobigerinella sp. cf. G. bolivariana, axial section, 63X. 14, 15: Morozovella sp. cf. M. aragonensis (Nutall, 1930), equatorial section, 90X. 16: Morozovella sp., axial section, 90X. 17: Acarinina sp., axial section, 63X. 18: Subbotina sp., equatorial section, 90X. 19: Lenticulina sp. cf. L. jeffersonensis Garrett, 1939, side view, 30X. (Continue on next page). 


\begin{tabular}{|c|c|c|c|c|c|}
\hline & $\mathscr{\theta}$ & $\begin{array}{c}\text { Parras } \\
\text { Basin }\end{array}$ & $\begin{array}{c}\text { La Popa } \\
\text { Basin }\end{array}$ & & $\begin{array}{c}\text { Sabinas } \\
\text { Basin }\end{array}$ \\
\hline-1 & | & & Carroza & & Hermanas \\
\hline$\pi$ & & & Viento & & (El Arco) \\
\hline- & & & Adjuntas & & Adjuntas \\
\hline-1 & 0 & Rancho & Upper & & \\
\hline-1 & $\overline{8}$ & & & a & Upper \\
\hline & $\frac{\pi}{\pi}$ & & Upper & - & Potrerillos? \\
\hline & & Las Encinas & & $=$ & \\
\hline$\infty$ & . & Cerro Grande & Siltstone & 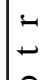 & \\
\hline $\begin{array}{l}7 \\
0\end{array}$ & : & Las Imágenes & $\begin{array}{c}\text { Lower } \\
\text { Mudstone }\end{array}$ & م & Escondido \\
\hline $\begin{array}{l}0 \\
0 \\
0\end{array}$ & $\sum^{\pi}$ & Cañón del Tule & $\begin{array}{c}\text { Lower } \\
\text { Siltstone }\end{array}$ & & \\
\hline- & 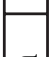 & Cerro Huerta & & & Olmos \\
\hline-1 &.$\frac{\pi}{7}$ & & & & \\
\hline$\cup$ & 气ี & Cerro del Pueblo & & & San Miguel \\
\hline & U & & Parras & & Upson \\
\hline
\end{tabular}

Figure 6. Stratigraphic correlation between units of the Parras, La Popa and Sabinas basins, based on data here presented and on those of Bermúdez-Santana, 2003; Chávez-Cabello et al., 2004; Eberth et al., 2004; Goldhammer and Johnson, 1999; Kirkland et al., 2000; Lawton et al., 2001; Soegaard et al., 2003; Vega and Perrilliat, 1995.

Rancho Nuevo Formation in the Parras Basin is extended to the Eocene, indicating that the Rancho Nuevo contains strata equivalent to the Adjuntas and Viento formations in the La Popa Basin, and the Adjuntas Formation and El Arco Lentil in the Sabinas Basin. Eustasy and diapirism during Paleocene and Eocene times played important roles in deposition of Tertiary strata in Northeastern Mexico.

\section{Acknowledgements}

The original manuscript was reviewed by T. Lawton (Department of Geological Sciences, New Mexico State

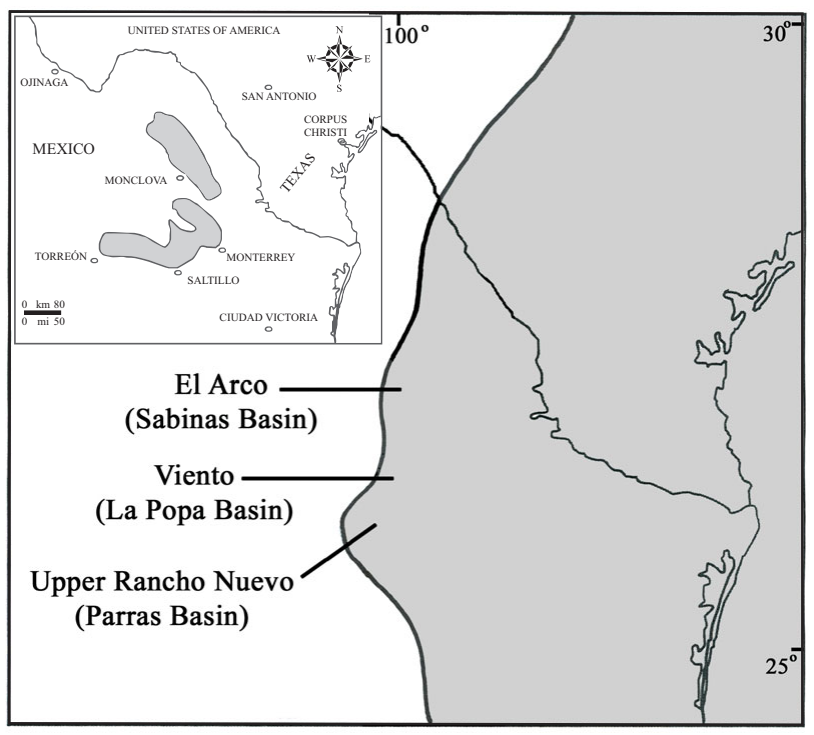

Figure 7. Inferred Eocene shoreline with approximate location of deposits of El Arco Lentil (Hermanas formation), Viento/Carroza and upper Rancho Nuevo formations. See Figure 1.1 for Recent geographic reference.

University), S. Eguiluz (retired geologist of PEMEX and consultant, Manchester, UK) and G. Chávez (Facultad de Ciencias de La Tierra, UANL), and we thank their valuable suggestions. T. Nyborg helped with English grammar and other useful suggestions. Our gratitude to H. Filkorn (Los Angeles County Museum), for his valuable help in identification of corals. Support provided by E. García-Cordero (Departamento de Paleontología, Instituto de Geología, UNAM) and L. Martín-Medrano (Facultad de Ciencias, UNAM) is highly appreciated.

\section{Bibliographic References}

Aldrich, T.H., 1931, Description of a Few Alabama Eocene Species and Remarks on Varieties: Geological Survey of Alabama, Museum Paper 12, 6-7.

Allmon, W.D., 1996, Evolution and systematics of Cenozoic American Turritellidae (Gastropoda). I. Paleocene and Eocene species related to "Turritella mortoni Conrad" and "Turritella humerosa Conrad" from the U.S. Gulf and Atlantic Coastal Plains: Palaeontographica Americana, 59, 1-134.

Allmon, W.D., 2005, Kapalmerella, a new name for the genus Palmerella Allmon, 1996 (Gastropoda: Turritellidae) preoccupied by Palmerella Cameron 1908 (Insecta: Hymenoptera): Journal of Paleontology, 79, 1234.

Figure 5. (Continued). 20 - 22: Flabellum sp., locality IGM 3599, El Arco Lentil, Hermanas formation, Sabinas Basin, Coahuila, Middle Eocene. 20: Hypotype IGM-7833, approximately oblique - longitudinal cross section of a corallum; the upper margins of septa appear to be exsert, 5X; 21: Hypotype IGM-7834, transverse cross section near the calicular margin of a corallum; four complete cycles of septa present (48 septa), columella absent, 10X; 22: Hypotype IGM-7835, transverse cross section near the base of a corallum; three complete cycles of septa present (24 septa), columella absent, 15X. 23 - 25: Kapalmerella mortoni postmortoni (Harris, 1894), locality IGM 1973, Cerro La Carroza, Adjuntas Formation, La Popa Basin, Nuevo León, Lower Eocene (Ypresian). 23: Hypotype IGM-7836, with a left valve of Ostrea (Turkostrea) escondida Perrilliat and Vega, 1993 attached, X1.5. 24: Hypotype IGM-7837, X2.0. 25: Hypotype IGM-7838, X0.7. 26: Venericardia planicosta (Lamarck, 1801), hypotype IGM-7839, locality IGM 1973, Cerro La Carroza, Adjuntas Formation, La Popa Basin, Nuevo León, Lower Eocene (Ypresian), X0.8. 
Bermúdez-Santana, J.C., 2003, Sequence stratigraphy and depositional history of the upper Cañón del Tule, Las Imágenes, and lower Cerro Grande formations, central Parras Basin, northeastern Mexico: University of Texas at Austin, Ph.D, Thesis, 210 p.

Berry, E.W., 1923, A new Hercoglossa from the Eocene of Peru: American Journal of Science, 5th series, 6, 427-431.

Chávez-Cabello, G., 2005, Deformación y magmatismo Cenozoico en el sur de la Cuenca de Sabinas, Coahuila, México: Posgrado en Ciencias de La Tierra, UNAM, Tesis Doctoral, 266 p.

Chávez-Cabello, G., Cossío-Torres, T., Peterson-Rodríguez, R.H., 2004 , Change of the maximum principal stress during the Laramide orogeny in the Monterrey salient, northeast México: Geological Society of America, Special Paper, 383, 145-160.

Conrad, T.A., 1857, Descriptions of Cretaceous and Tertiary fossils, in Emory, W.H. (ed.), Report on the United States and Mexican boundary Survey: U.S. 34th congress 1st. session, Senate Ex Document 108 and House Ex Document, 135, 1(2), 140-174.

Corona-Esquivel, R., Tritlla, J., Benavides-Muñoz, M.E., PiedadSánchez, N., Ferrusquía.Villafranca, I., 2006, Geología, estructura y composición de los principales yacimientos de carbón mineral en México: Boletín de la Sociedad Geológica Mexicana, 58, 1, 141-160.

Eberth, D.A., Delgado de Jesús, C.R., Lerbekmo, J.F., Brinkman, D.B., Rodríguez-de la Rosa, R.A., Sampson, S.D., 2004, Cerro del Pueblo Fm (Difunta Group, Upper Cretaceous), Parras Basin, southern Coahuila, Mexico: reference sections, age and correlation: Revista Mexicana de Ciencias Geológicas, 21, 3, 335-352.

Echánove, E.O., 1988, Geología Petrolera de la Cuenca de Burgos: Boletín, Asociación Mexicana de Geólogos Petroleros, 38, 1, 1-74.

Eguiluz-de Antuñano, S., 2001, Geologic evolution and gas resources of the Sabinas Basin in Northeastern México: American Association of Petroleum Geologists, Memoir, 75, 241-270.

Eguiluz-de Antuñano, S., 2004, Tectónica Laramide en la Cuenca de Burgos, México: Geos, 24, 2, 307-308

Eguiluz-de Antuñano, S., 2007, Laramide deformation in the Burgos Basin, Northeast México, in Bob Perkins Research Conference: 2007 Gulf Coast Society-SEPM, Houston, 1-18.

Eguiluz-de Antuñano, S., Amezcua-Torres, N., 2003, Coalbed methane resources of the Sabinas Basin, Coahuila, México: American Association of Petroleum Geologists, Memoir, 79, 395-402.

Eguiluz-de Antuñano, S., Aranda-García, M., Marrett, R., 2000, Tectónica de la Sierra Madre Oriental, México: Sociedad Geológica Mexicana, Boletín, 53, 1-26.

Flores-Espinoza, E., 1989, Stratigraphy and Sedimentology of the Upper Cretaceous Terrigenous Rocks and Coal of the Sabinas-Monclova Area, Northern Mexico: Ph. D. Thesis, The University of Texas at Austin, 315 p.

Flores-Galicia, E., 1988, Geología y reservas de los yacimientos de carbón en la República Mexicana, en Salas, G.P. (Ed.) Geología de México: México, Fondo de Cultura Económica, p. 175-217.

Gray, G.G., Pottorf, R.J., Yurewicz, D.A., Mahon, K.I., Pevear, D.R.,Chuchla, R.J., 2001, Thermal and chronological record of syn- to post-Laramide burial and exhumation, Sierra Madre Oriental, Mexico: American Association of Petroleum Geologists, Memoir, 79, 159-181.

Garrett, J.B., 1939, Some Middle Tertiary Smaller Foraminifera from Subsurface Beds of Jefferson County, Texas: Journal of Paleontology, 13, 6, 575-579.

Giles, K.A., Lawton, T.F., 1999, Attributes and Evolution of an Exhumed Salt Weld, La Popa Basin, Northeastern Mexico: Geology, 27, 323-326.

Giles, K.A., Lawton, T.F., 2002, Halokinetic sequence stratigraphy adjacent to El Papalote Diapir, La Popa Basin, Northeastern Mexico: Bulletin of the American Association of Petroleum Geologists, $86,823-841$

Goldhammer, R.K., Johnson, C.A., 1999, Mesozoic sequence stratigraphy and paleogeographic evolution of northeast Mexico: Geological Society of America, Special Paper 340, 1-58.

Harris, G.D., 1894, On the geological position of the Eocene deposits of Maryland and Virginia: American Journal of Science, 3, 47,
301-304.

Ifrim, C., Stinnesbeck, W., Schafhauser, A., 2005, Maastrichtian shallowwater ammonites of northeastern Mexico: Revista Mexicana de Ciencias Geológicas, 22, 48-64.

Kirkland, J.I., Hernández-Rivera, R., Aguillón-Martínez, M.C., Delgado de Jesús, C.R., Gómez-Núñez, R., Vallejo, I., 2000, The Late Cretaceous Difunta Group of the Parras Basin, Coahuila, Mexico, and its vertebrate fauna, in Society of Vertebrate Paleontology Annual Meeting, Field Trip Guide Book: Mexico, Universidad Autónoma del Estado de Hidalgo, Avances en Investigación, 3, 133-172.

Klosterman, S., Sandy, M.R., Vega, F.J., Giles, K., Graf, K., Shelley, D., Solé, J., 2007, New Paleocene Rhynchonellide Brachiopods from the Potrerillos Formation, Northeast Mexico: Journal of Paleontology, 81, 3: 483-489.

Lamarck, J.B.P.A. de M. De., 1801-1802, Mémoires sur les fossiles des environs de Paris comprenant la détermination des espèces qui appartinnent aux animaux marins sans vertèbres, et dont la plupart son figurés dans la collection des vélins du Muséum: Annales du Muséum National d’Histoire Naturelle, 1, 383-391. [Reprinted by The Paleontological Research Institution, Ithaca, NY, 1978].

Laudon, R.C., 1975, Stratigraphy and petrology of the Difunta Group, La Popa and Eastern Parras basins, northeastern Mexico: $\mathrm{Ph} \mathrm{D}$. Thesis, The University of Texas at Austin, 294 p.

Lawton, T., Vega, F.J., Giles, K.A., Rosales-Domínguez, M.C., 2001, Stratigraphy and Origin of the La Popa Basin, Nuevo León and Coahuila, Mexico: In C. Bartolini, R.T. Buffler, and A. Cantu-Chapa, eds. The Western Gulf of Mexico Basin: Tectonics, Sedimentary Basins, and Petroleum Systems. Tulsa,Oklahoma, American Association of Petroleum Geologists, Memoir 75, 219-240.

Loeblich, A.R., Tappan, H., 1986, Foraminiferal Genera and their Classification. Van Nostrand Reinhold, 970 pp. +847 pl.

McBride, E.F., Weidie, A.L. Jr., Wolleben, J.A., 1975, Deltaic and associated deposits of Difunta Group (Late Cretaceous to Paleocene), Parras and La Popa basins, northeastern Mexico, in Broussard, M.L.S., ed. Deltas: Houston, Houston Geological Society, 485-522.

Nuttall, W.L.F., 1930, Eocene foraminifera from México: Journal of Paleontology, 4, 271-293.

Perrilliat, M.C., Vega, F.J., 1993, Early Eocene ostreids from the Adjuntas Formation (Difunta Group), northeastern Mexico: Tulane Studies on Geology and Paleontology, 26, 1: 15-25.

Perrilliat, M.C., Vega, F.J., 2003, Lower Eocene large ostreids from The Viento Formation; a stratigraphic and paleoecologic contribution to La Popa basin, Nuevo León, Mexico: American Association of Petroleum Geologists, Memoir 79: 419-426.

Perrilliat, M.C., Avendaño, J., Vega, F.J., Solé, J., 2006, Lower Eocene gastropods from El Bosque Formation, central Chiapas, Mexico: The Veliger, 48, 3, 37-55.

Robeck, R., Pesquera, C., Rubén, V., Ulloa, A.S., 1956, Geología y depósitos de carbón de la región de Sabinas, Estado de Coahuila, en XX Congreso Geológico Internacional: México, D.F., 109 p.

Soegaard, K., Ye, H., Halik, N., Daniels, A.T., Arney, J., Garrick, S., 2003, Stratigraphic evolution of latest Cretaceous to early Tertiary Difunta foreland basin in northeastern Mexico: Influence of salt withdrawal on tectonically induced subsidence by the Sierra Madre Oriental fold and thrust belt: American Association of Petroleum Geologists, Memoir 79: 364-394.

Squires, R.L., Demetrion, R.A., 1992, Paleontology of the Eocene Bateque Formation Baja California Sur, Mexico: Los Angeles County Museum, Contributions in Science, 434, 1-55.

Stephenson, L.W., 1927, Notes on the stratigraphy of the Upper Cretaceous formations of Texas and Arkansas: American Association of Petroleum Geologists, Bulletin, 11, 1, 1-17.

Steurbaut, E., 2006, Ypresian: Geologica Belgica, 9, 1-2, 73-93.

Vega, F.J., Perrilliat, M.C., 1989a, La presencia del Eoceno marino en la cuenca de La Popa (Grupo Difunta), Nuevo León: orogenia postypresina: México, Universidad Nacional Autónoma, Instituto de Geología, Revista 8, 1: 67-70.

Vega, F.J., Perrilliat, M.C., 1989b, On a new species of Venericardia 
from the lower Eocene in northeastern Mexico: Tulane Studies in Geology and Paleontology, 22, 3: 101-106.

Vega, F.J., Perrilliat, M.C., 1989c. Moluscos del Maastrichtiano de la Sierra El Antrisco, Nuevo León: México, Universidad Nacional Autónoma, Instituto de Geología, Paleontología Mexicana,55, 1-63.

Vega, F.J., Perrilliat, M.C., 1992, Freshwater gastropods from lower Eocene Difunta Group, northeastern Mexico: Journal of Paleontology, 66, 4: 603-609.

Vega, F.J., Perrilliat, M.C., 1995, On some Paleocene invertebrates from the Potrerillos Formation (Difunta Group) northeastern Mexico: Journal of Paleontology, 69, 5: 862-869.
Vega, F.J., Mitre-Salazar, L.M., Martínez-Hernández, E., 1989, Contribución al conocimiento de la estratigrafía del Grupo Difunta (Cretácico Superior-Terciario) en el noreste de México: México, Universidad Nacional Autónoma, Instituto de Geología, Revista 8, 2: 179-187.

Wolleben, J.A., 1977, Paleontology of the Difunta Group (Upper Cretaceous-Tertiary) in northeastern Mexico: Journal of Paleontology, 51, 2, 373-398.

Manuscript received: July 5, 2007

Corrected manuscript received: August 13, 2007

Manuscrito aceptado: August 20, 2007 